\title{
Anaerobic utilization of pectinous substrates at extremely haloalkaline conditions by Natranaerovirga pectinivora gen. nov., sp. nov., and Natranaerovirga hydrolytica sp. nov., isolated from hypersaline soda lakes
}

\author{
D. Y. Sorokin $\cdot$ T. P. Tourova $\cdot$ A. N. Panteleeva $\cdot$ \\ E. N. Kaparullina $\cdot$ G. Muyzer
}

Received: 7 November 2011/Accepted: 12 January 2012/Published online: 1 February 2012

(C) The Author(s) 2012. This article is published with open access at Springerlink.com

\begin{abstract}
Anaerobic enrichments at $\mathrm{pH}$ 10, with pectin and polygalacturonates as substrates and inoculated with samples of sediments of hypersaline soda lakes from the Kulunda Steppe (Altai, Russia) demonstrated the potential for microbial pectin degradation up to soda-saturating conditions. The enrichments resulted in the isolation of six strains of obligately anaerobic fermentative bacteria, which represented a novel deep lineage within the order Clostridiales loosely associated with the family Lachnospiraceae. The isolates were rod-shaped and formed terminal round endospores. One of the striking features of the novel group is a very narrow substrate spectrum for growth, restricted to galacturonic acid and its polymers (e.g. pectin). Acetate and formate were the
\end{abstract}

Communicated by A. Oren.

Nucleotide sequence accession numbers: the GenBank/EMBL accession numbers of the 16S rRNA gene sequences obtained in this work are GQ863486-GQ863487, GQ922845-GQ922846 and JN801138-JN801139.

Electronic supplementary material The online version of this article (doi:10.1007/s00792-012-0431-6) contains supplementary material, which is available to authorized users.

D. Y. Sorokin $(\bowtie) \cdot$ T. P. Tourova

Winogradsky Institute of Microbiology,

Russian Academy of Sciences, Prospect 60-let Octyabrya 7/2,

117811 Moscow, Russia

e-mail: soroc@inmi.ru; d.sorokin@tudelft.nl

D. Y. Sorokin · G. Muyzer

Environmental Biotechnology Group,

Department of Biotechnology, Delft University of Technology,

Delft, The Netherlands

\section{A. N. Panteleeva}

Bioengineering Centre, Russian Academy of Sciences,

Prospect 60-let Octyabrya 7/1, 117811 Moscow, Russia final fermentation products. Growth was possible in a $\mathrm{pH}$ range from 8 to 10.5 , with an optimum at $\mathrm{pH} 9.5-10$, and in a salinity range from 0.2 to $3.5 \mathrm{M} \mathrm{Na}^{+}$. On the basis of unique phenotypic properties and distinct phylogeny, the pectinolytic isolates are proposed to be assigned to a new genus Natranaerovirga with two species $N$. hydrolytica $\left(\mathrm{APP} 2^{\mathrm{T}}=\mathrm{DSM} 24176^{\mathrm{T}}=\mathrm{UNIQEM}^{\mathrm{U}} 806^{\mathrm{T}}\right)$ and $N$. pectinivora $\left(\mathrm{AP}^{\mathrm{T}}=\mathrm{DSM} 24629^{\mathrm{T}}=\mathrm{UNIQEM} \mathrm{U}^{\mathrm{T}} 85^{\mathrm{T}}\right)$.

Keywords Pectin Pectinolytic $\cdot$ Haloalkaliphilic .

Soda lakes

\section{Introduction}

Pectin, a natural polymer of galacturonic acid, is an important component of plant biomass as a part of hemicelluloses. It is degraded by pectinolytic microorganisms producing an extracellular enzymatic complex consisting of exo- and endopectinases, pectate lyase and methylesterase (Jayani et al. 2005). The pectin hydrolysis is an important process, both for natural habitats and for industrial

\section{E. N. Kaparullina \\ Institute of Physiology and Biochemistry of Microorganisms, \\ Russian Academy of Sciences, Puschino, Russia}

Present Address:

G. Muyzer

Department of Aquatic Microbiology,

Institute for Biodiversity and Ecosystem Dynamics,

University of Amsterdam, Amsterdam, The Netherlands 
processing of food and textile (Kashyap et al. 2001; Sarethy et al. 2011). The first discovered pectinolytics were anaerobic clostridia acting as a flax degumming ("retting") agent (Omelyansky 1904). Most of the known pectinolytic microorganisms grow optimally at acidic and neutral $\mathrm{pH}$, while evidence for pectinolysis at high $\mathrm{pH}$ and/or high salt are scarce, although potentially useful for application in the food and textile industry. Producers of alkalitolerant pectinases are known among non salt-tolerant aerobes, such as various bacilli (Hoondal et al. 2002). With respect to specific haloalkaline habitats, such as soda lakes and soda soils, only two cases of pectin degradation have been reported so far, both describing novel members of the phylum Bacteroidetes and represented by the genera Alkaliflexus and Natronoflexus (Zhilina et al. 2004; Sorokin et al. 2011). These organisms are low salt tolerant and multisubstrateutilizing saccharolytic fermentative alkaliphiles able to hydrolyze pectin among other polymers. However, the question remained, whether pectin degradation is possible in saturated soda brines with salinity above $2 \mathrm{M} \mathrm{Na}^{+}$.

In this study, we focused on the microbial degradation of pectin and related polymers in anoxic sediments of hypersaline soda lakes and soda soils. The high salt enrichments resulted in the isolation of six strains of haloalkaliphilic clostridia representing a novel phylogenetic lineage at the family level, whose properties are described below.

\section{Methods}

Samples

Samples of the top $5 \mathrm{~cm}$ sediments from five hypersaline soda lakes and 2 soda solonchak soils were taken in Kulunda Steppe (Altai, Russia) in July 2009. The brine $\mathrm{pH}$ varied from 9.95 to 10.5 , the total salinity from 100 to $250 \mathrm{~g} \mathrm{l}^{-1}$ and the soluble carbonate alkalinity from 1.1 to $2.5 \mathrm{M}$. The soils contained $5-7 \%(\mathrm{w} / \mathrm{w})$ of soluble salts with an alkalinity of $0.2-0.5 \mathrm{M}$ and a $\mathrm{pH}$ of $10.1-10.2$ of the water extract. The individual sediment and soil samples were mixed in equal proportions to obtain a single sediment and a single soil sample, which were subsequently used as an inoculum to enrich for haloalkaliphilic pectinolytics.

Enrichment and cultivation of anaerobic pectinolytic haloalkaliphiles

Enrichment and cultivation of haloalkaliphilic pectinolytics was performed at $28^{\circ} \mathrm{C}$ on a mineral medium containing sodium carbonate buffer $\left(0.6-3.0 \mathrm{M} \mathrm{Na}^{+}\right)$with $\mathrm{pH}$ 10 (stable after sterilization) and $0.5 \mathrm{~g} \mathrm{l}^{-1}$ of $\mathrm{K}_{2} \mathrm{HPO}_{4}$.
After sterilization at $120^{\circ} \mathrm{C}$ for $30 \mathrm{~min}$, the medium was supplemented with $10 \mathrm{mg} \mathrm{l}^{-1}$ of yeast extract, $4 \mathrm{mM}$ $\mathrm{NH}_{4} \mathrm{Cl}, 1 \mathrm{mM} \mathrm{MgSO}$, and $1 \mathrm{ml} \mathrm{l}^{-1}$ each of acidic trace metal solution and vitamin mix (Pfennig and Lippert 1966). Carbohydrates were added at concentrations $1 \mathrm{~g} \mathrm{l}^{-1}$ from $10 \%$ (w/v) sterile stock solutions (sugars were filter-sterilized, and polymers were autoclaved at $110^{\circ} \mathrm{C}$ for $30 \mathrm{~min}$ at neutral $\left.\mathrm{pH}\right)$. Anaerobic cultivation was performed either in $15 \mathrm{ml}$ Hungate tubes with $10 \mathrm{ml}$ medium, or in $50 \mathrm{ml}$ serum bottles with $40 \mathrm{ml}$ medium with argon in the gas phase. The tubes and bottles were closed with black butyl rubber stoppers and made anoxic by 5 cycles of evacuation-argon flushing with final addition of $1 \mathrm{mM} \mathrm{HS}^{-}$as a reductant. Solid medium was prepared by 1:1 mixing of the complete liquid media and $4 \%(\mathrm{w} / \mathrm{v})$ washed agar at $50^{\circ} \mathrm{C}$. The plates were incubated in closed jars under argon with an oxygen-consuming catalyzer (Oxoid). The $\mathrm{pH}$ dependence for growth was examined at $\mathrm{Na}^{+}$content of $0.6 \mathrm{M}$, using the following filter-sterilized buffering systems: for $\mathrm{pH} 6-8,0.1 \mathrm{M}$ HEPES $+\mathrm{NaCl} / \mathrm{NaHCO}_{3}$; for $\mathrm{pH} 8.5-11$, a mixture of sodium bicarbonate/sodium carbonate containing $0.1 \mathrm{M}$ $\mathrm{NaCl}$. Because the $\mathrm{pH}$ was changing during cultivation (mostly at highest starting values), the final values at the end of the exponential growth phase were taken into consideration of the growth $\mathrm{pH}$ profiles. To study the influence of salt concentration on growth, sodium carbonate media at $\mathrm{pH} 10$, containing 0.2 and $4.0 \mathrm{M}$ of total $\mathrm{Na}^{+}$were mixed in different proportions. The polymers used were apple pectin (Sigma), polygalacturonic acid (Sigma), pectic and polypectic acids (Baker). Although according to the chemical textbooks, the latter three substances have the same chemical composition, a difference was observed in their microbial utilization, which indicated different properties. Pectin was sterilized as $10 \%$ $(w / v)$ suspension at $110^{\circ} \mathrm{C}$, while polygalacturonates were first washed several times in distilled water, resuspended at $5 \%$ (w/v), solubilized by neutralization with $2 \mathrm{M} \mathrm{NaOH}$ and sterilized by filtration. Upon addition to alkaline media, the polymers formed an insoluble amorphous precipitate. Prolonged incubation of the polymers in alkaline media at $\mathrm{pH}$ between 10 and 11 and temperature up to $40^{\circ} \mathrm{C}$ did not result in any detectable spontaneous release of reducing sugars into the medium.

\section{Analyses}

The growth experiments were performed in duplicate. Growth was determined by following an increase in optical density at $600 \mathrm{~nm}\left(\mathrm{OD}_{600}\right)$ and the evidences for polymer degradation was observed by gradual disappearance of the precipitate in comparison with the uninoculated controls. In the case of cultures grown on pectin substrates, the solids 

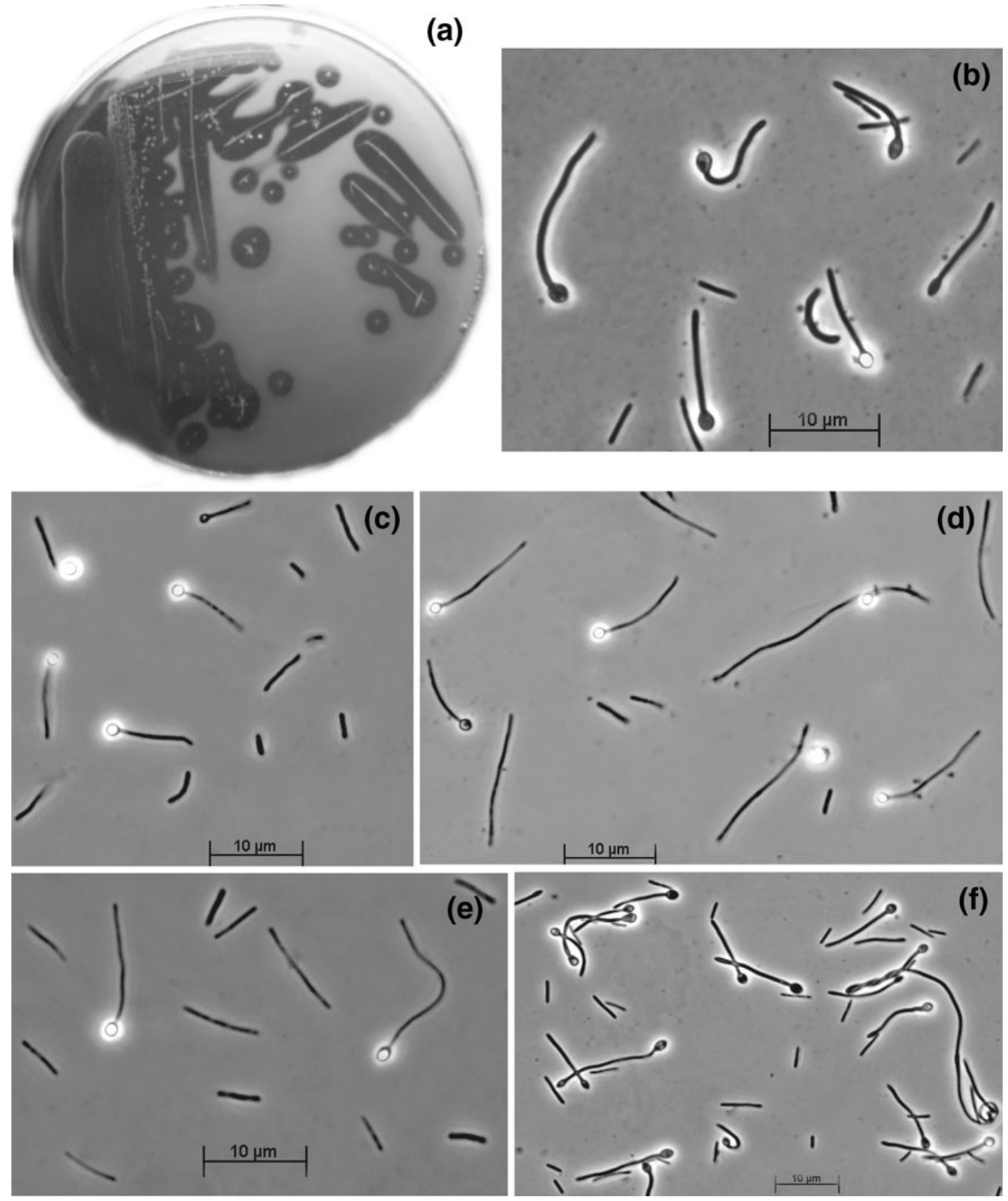

(f)

Fig. 1 Morphology of haloalkaliphilic pectinolytic isolates grown at $\mathrm{pH}$ 10. a Formation of clearance zones around colonies of strain AP3 during growth on polygalacturonate. Cell morphology (phase-contrast

microphotographs): b strain APP2, c strain AP3, d strain APG1, e strain $\mathrm{APG} 2$, $\mathbf{f}$ strain APA1

were removed before the cell density measurements by a brief low-speed centrifugation. The growth rate was measured during the exponential increase of the biomass. Fermentation products were analyzed by HPLC anionic chromatography (BioRad, HPX-87-H column at $60^{\circ} \mathrm{C}$, eluent $5 \mathrm{mM} \mathrm{H}_{2} \mathrm{SO}_{4}$ solution at $0.6 \mathrm{ml} \mathrm{min}{ }^{-1}$, $\mathrm{UV}$ and $\mathrm{RI}$ detectors) after neutralization of the supernatant. Reducing sugars were detected by the nitrosalicylate method (Miller 1959) after the removal of solids by high-speed centrifugation. Hydrolytic activity was qualitatively assayed by the agar diffusion method. Essentially, the cultures were grown at $\mathrm{pH} 10$ with polygalacturonate until its complete 
Table 1 Pectinolytic strains isolated from soda lakes and soda soils in Kulunda Steppe at pH 10

\begin{tabular}{|c|c|c|c|c|c|}
\hline \multirow[t]{2}{*}{ Strain } & \multirow[t]{2}{*}{ Source } & \multicolumn{2}{|c|}{ Enrichment conditions } & \multirow[t]{2}{*}{ DSM number } & \multirow{2}{*}{$\begin{array}{l}\text { 16S rRNA gene } \\
\text { accession number }\end{array}$} \\
\hline & & Total $\mathrm{Na}^{+}(\mathrm{M})$ & Polymer substrate & & \\
\hline APG1 & Lake sediments & 0.6 & Polygalacturonate & DSM24177 & GQ863486 \\
\hline APG2 & Soda soils & 0.6 & Polygalacturonate & & JN801139 \\
\hline APA1 & Lake sediments & 0.6 & Pectic acid & & JN801138 \\
\hline $\mathrm{APP} 2^{\mathrm{T}}$ & Lake sediments & 3.0 & Polypectate & DSM24176 & GQ863487 \\
\hline AP2 & Lake sediments & 2.0 & Apple pectin & & GQ922845 \\
\hline $\mathrm{AP} 3^{\mathrm{T}}$ & Soda soils & 0.6 & Apple pectin & DSM24629 & GQ922846 \\
\hline
\end{tabular}

consumption and the cells were harvested by centrifugation and disrupted by sonication to prepare the cell-free extract. The supernatant was filter-sterilized and 10 times concentrated on Centricon spin filter (Millipore) with pore size of $10 \mathrm{kDa}$. The fractions were applied into the wells cut in $1 \%$ agar containing the $\mathrm{pH}$ buffers used for cultivation (see above) with the final $\mathrm{Na}^{+}$concentration $0.6 \mathrm{M}$ and supplied with $1 \mathrm{~g} / \mathrm{l}$ of polygalacturonate. The plates were incubated at $30^{\circ} \mathrm{C}$ for $8 \mathrm{~h}$ anaerobically inside the gas-tight containers and the zones of hydrolysis were visualized by staining with $0.05 \%$ Ruthenium Red (Gang et al. 2010). Phase-contrast microphotographs were obtained with a Zeiss Axioplan Imaging 2 microscope (Göttingen, Germany). Polar lipids for fatty acid composition were extracted from $1 \mathrm{~g}$ of wet cell pellet with acidic methanol and the fatty acid methyl esters were analyzed by GC-MS according to Zhilina et al. (1997). For the total polar lipid analysis, the cells were extracted with chloroform-methanol $(1: 2, \mathrm{v} / \mathrm{v})$ on ice twice and the polar lipid fraction was resolved by two-dimensional TLC (Kieselgel 60, $10 \times 10 \mathrm{~cm}$, Merck) using chloroform-methanol-water (60:25:4) in the first direction, followed by chloroformacetic acid-methanol-water $(85: 15: 12: 4)$ in the second direction. Plates were sprayed with various specific reagents for detection of different phospholipids (Kates 1972). Catalase activity was measured iodimetrically according to Sumner and Dounce (1963).

The isolation of the DNA and determination of the $\mathrm{G}+\mathrm{C}$ content of the DNA was performed according to Marmur (1961) and Marmur and Doty (1962), respectively. DNADNA hybridization was performed by thermal spectrophotometry according to De Ley et al. (1970). For molecular analysis, the DNA was extracted from the cells using alkaline SDS lysis at $60^{\circ} \mathrm{C}$ and purified with the Wizard Preps Kit (Promega, USA). The nearly complete 16S rRNA gene was obtained using the general bacterial PCR primers 11f and 1492r (Lane 1991). The sequences were aligned with sequences from GenBank using CLUSTAL W and a phylogenetic tree was reconstructed using the neighbourjoining algorithm in the TREECONW program package (van de Peer and de Wachter 1994).

\section{Results and discussion}

Enrichment and isolation of pectinolytic haloalkaliphiles

Anaerobic enrichments at $\mathrm{pH} 10$ with apple pectin and linear polymers of galacturonic acids using soda lake sediments and soda soils as inoculum were positive at salt concentrations up to $4 \mathrm{M} \mathrm{Na}^{+}$, indicating a potential for anaerobic pectin degradation up to soda-saturating conditions. However, the growth at $4 \mathrm{M} \mathrm{Na}^{+}$was extremely slow and pure culture isolation failed at these conditions. At salt concentrations between 0.6 and $3 \mathrm{M} \mathrm{Na}^{+}$, the enrichments were stable and were dominated by clostridial morphotypes with long rod-shaped cells forming terminal spore. Plating of these enrichments resulted in colony formation with characteristic clearance zone indicating the ability to hydrolyze insoluble pectin polymers (Fig. 1a). As a result, six pure cultures were obtained dominating in six different enrichments (Table 1). All of them were represented by rod-shaped non-motile cells with variable length forming terminal ellipsoid or round endospores (Fig. 1b-f).

\section{Identification}

Phylogenetic analysis based on 16S rRNA gene sequencing demonstrated that all six isolates belong to the order Clostridiales forming a deep lineage (max. 89\% sequence similarity to described species) with two subgroups (APP2 and the other 5 strains) with sequence similarity between the subgroups of 94-95\%. Preliminary Blast analysis showed that the novel lineage was distant from all ten currently recognized families of the order Clostridiales but appeared to be loosely associated with the members of the family Lachnospiraceae (Cotta et al. 2009; Rainey 2009) (Fig. 2; Supplementary Fig. 1). Among them were several "representatives" of the genera Clostridium and Eubacterium, which, on the first glance, is confusing. However, closer inspection clearly showed, that this are misclassified members of the family Lachnospiraceae. The association with this family of the novel isolates was also evident from 
Fig. 2 Phylogenetic position of haloalkaliphilic pectinolytic strains within the order Clostridiales based on $16 \mathrm{~S}$ rRNA gene sequence analysis. Tree topography and evolutionary distances are obtained by the neighborjoining method with Jukes and Cantor distances. The scale bar represents 5 nucleotide changes per 100 nucleotides. The numbers on the nodes indicate bootstrap values above $70 \%$

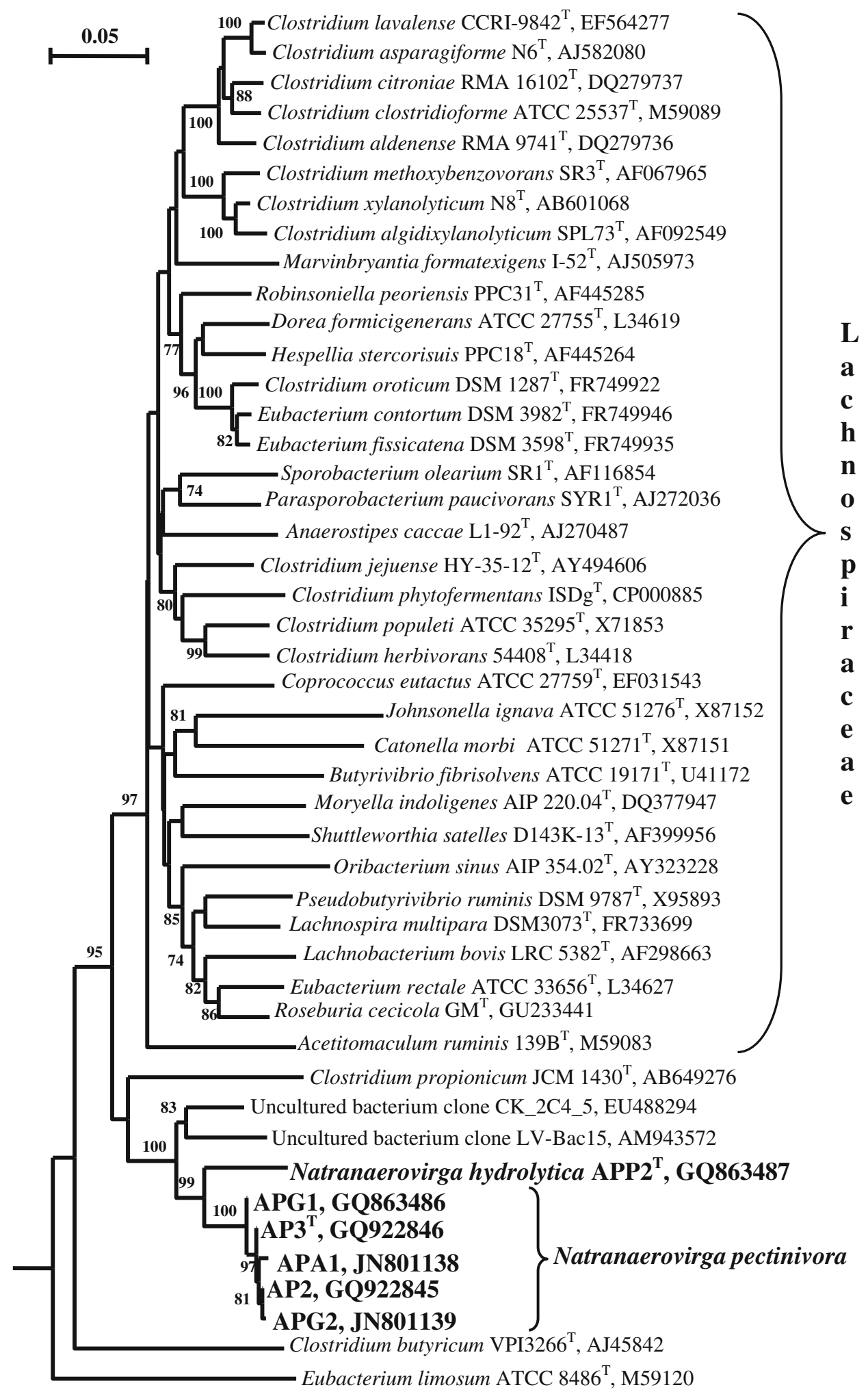

the RDP Classifier, which gave $93 \%$ probability for the clustering. On the other hand, the position of the novel group will remain uncertain until more sequences of related organisms appear in the database. It is worth to notice that some of the representatives of this family are typical anaerobic pectinolytics, such as members of the type genus Lachnospira (Rainey 2009). Strains APP2 ${ }^{\mathrm{T}}$ and $\mathrm{AP} 3^{\mathrm{T}}$ were selected as the representative type strains of the two 
Table 2 Comparison of the PLFA profiles of strains AP3 and APP2 and its closest relative (Cotta et al. 2009) and a typical clostridial species (Park et al. 2001)

\begin{tabular}{|c|c|c|c|c|}
\hline Fatty acid & AP3 & APP2 & $\begin{array}{l}\text { Robinsoniella } \\
\text { peoriensis }\end{array}$ & $\begin{array}{l}\text { Clostridium } \\
\text { butyricum }\end{array}$ \\
\hline $11: 0$ & & & & 1.3 \\
\hline $13: 1$ & & & 2.7 & \\
\hline 3-OH13:0 & & & 8.2 & \\
\hline $14: 0$ & & & 11.4 & 9.3 \\
\hline a15 & 2.2 & & & 3.5 \\
\hline $15: 0$ & 1.6 & 2.0 & & 4.9 \\
\hline $15: 0 \mathrm{a}$ & & & & 1.8 \\
\hline $16: 1 \omega 5$ & 0.8 & 1.3 & & \\
\hline $16: 1 \omega 7 \mathrm{a}$ & & 1.4 & & \\
\hline $16: 1 \omega 7 \mathrm{c}$ & 11.5 & 10.7 & 11.9 & \\
\hline $16: 1 \omega 7 \mathrm{t}$ & 0.6 & & & \\
\hline $16: 1 \omega 9$ & 2.4 & 3.7 & & \\
\hline $16: 1 \omega 9 a$ & 1.7 & 4.8 & & \\
\hline $16: 0$ & 46.9 & 57.8 & 32.6 & 31.1 \\
\hline $16: 0 \mathrm{a}$ & & 1.1 & & \\
\hline a17 & 0.5 & & & \\
\hline $17: 1$ & 0.6 & & & 4.3 \\
\hline i17:1 & & & 7.1 & \\
\hline $17: 0$ & 1.6 & & & \\
\hline $18: 1 \omega 9$ & 0.8 & & 1.4 & 6.7 \\
\hline $18: 1 \omega 7 \mathrm{c}$ & 17.5 & 3.7 & 16.0 & 12.6 \\
\hline $18: 1 \omega 7 \mathrm{t}$ & 6.0 & & & \\
\hline $18: 0$ & 1.5 & & 1.3 & 6.9 \\
\hline $18: 1 \omega 7 \mathrm{a}$ & 1.5 & 2.3 & & \\
\hline $19: 0$ & & & 2.4 & 2.7 \\
\hline 19 сус & & & 2.1 & 0.8 \\
\hline $20: 1$ & & & & 1.5 \\
\hline
\end{tabular}

The dominant FA is in bold. Only the values above $0.5 \%$ are presented. The alkaliphilic strains were grown up to late logarithmic phase at $30^{\circ} \mathrm{C}, 0.6 \mathrm{M}$ total $\mathrm{Na}^{+}$and $\mathrm{pH} 10$ with galacturonic acid as substrate

subgroups. The level of DNA-DNA similarity between strain AP3, AP2 and APA1 was from 82 to $90 \%$ confirming their belonging to a single genetic species.

Chemotaxonomic comparison showed general similarity between PLFA (polar lipids fatty acids) profiles of the type strains and a closest cultured representative of the family Lachnospiraceae (Robinsoniella peoriensis) with a domination of 16:0 and 16:1 $\omega 7 \mathrm{c}$ (Table 2). On the other hand, the profiles of novel isolates differed from typical clostridia by the absence of $\mathrm{C} 14$ species. This might be a specific feature of alkaliphilic clostridia. The polar lipid profiles of the type strains were relatively complex and also significantly different from each other. The identified components included phosphatidylglycerol and diphosphatidylglycerol. Furthermore, both strains contained an aminophospholipid, a range of unidentified phospholipids (APP2-8, AP3-5), unidentified glycolipids (APP2-1, AP3 - 3) and unidentified polar lipids (APP2-1, AP3-2) (Supplementary Fig. 2).

Metabolic characteristics

The novel isolates have a very narrow substrate range and represent extremely specialized obligately anaerobic fermenters able to utilize only pectin (except strain APP2), polygalacturonates and galacturonic acid as growth substrates. In addition, strain APP2 utilized glucuronic acid. None of the following carbohydrates supported growth: D-glucose, D-fructose, galactose, D-mannose, D-maltose, sucrose, dextrose, $\alpha, \alpha$-trehalose, melibiose, melizitose, L-arabinose, L-sorbose, D-raffinose, D-ramnose, D-glucosamine, $N$-acetyl glucosamine, $\alpha$-methyl-glycoside, 2 -desoxyglucose, D-lactose, D-ribose, D-xylose, m-inositol, m-erythritol, L-arabinite, D-cellobiose, glycogen, starch, dextrine, xylan, laminarin, pullulan, alginate, CMC, and cellulose.

The enzyme complex apparently responsible for the hydrolysis of pectin and its analogs was detected both in the culture supernatant and in the cell fraction by the agar diffusion method, although the activity was obviously higher in the cell-free supernatant (Supplementary Fig. S3). The activity was optimal between the $\mathrm{pH} 9$ and 10 .

The main difference between strain APP2 and the other 5 strains was the preference of the latter subgroup for polymers over the monomer galacturonic acid, which was utilized much slower and usually after a prolonged lag phase. Such extreme substrate specialization has been reported for one of the pectinolytic (pectinophilic in author's interpretation) representatives of the Clostridiales, Lachnospira pectinoshiza (Cornick et al. 1994). The final products of galacturonic acid fermentation were acetate and formate. $\mathrm{H}_{2}$ was detected only in trace amounts and $\mathrm{CO}_{2}$ was not possible to detect because of the highly alkaline conditions. No growth was observed in the presence of oxygen in the gas phase and it was stimulated by the addition of reductants. Catalase activity was not detectable.

Influence of $\mathrm{pH}$ and sodium on the growth and activity

With galacturonic acid as substrate, the strains AP3 and APP2 grew at a $\mathrm{pH}$ between 8-8.2 and 10.5-10.6 with an optimum at $\mathrm{pH}$ 9.7-10 (Fig. 3a). The growth was chloride independent. In sodium carbonate buffer at $\mathrm{pH} 10$, growth occurred between 0.2 and $2.5 \mathrm{M}$ total $\mathrm{Na}^{+}$with an optimum at $0.4-0.6 \mathrm{M}$ in strains AP3, APA1 and APG1 and between 0.2 and $3.5 \mathrm{M} \mathrm{Na}^{+}$with an optimum at $1.0 \mathrm{M}$ in strain APP2 (Fig. 3b). According to these characteristics, the organisms belong to the high salt-tolerant obligate alkaliphiles. 


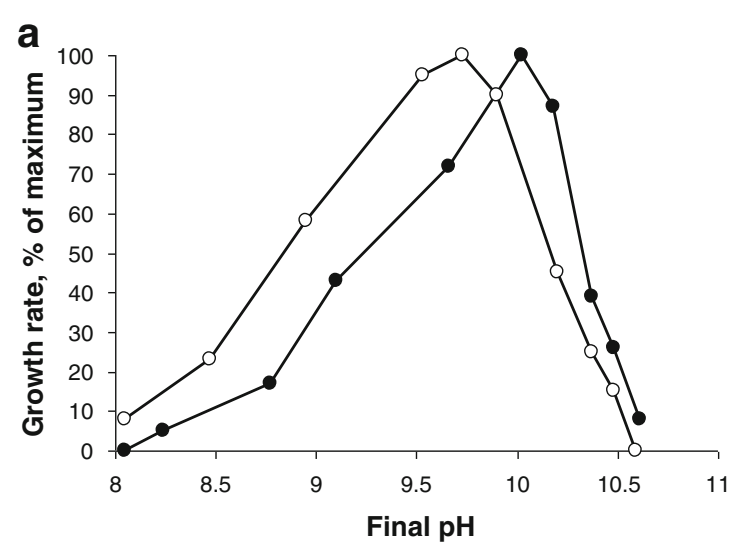

Fig. 3 Influence of $\mathrm{pH}$ at $0.6 \mathrm{M} \mathrm{Na}^{+}$(a) and of sodium carbonate at pH 10 (b) on anaerobic growth of strains AP3 (open circles) and APP2 (closed circles) with galacturonic acid. The experiments were performed in duplicates and the points represent the average values with standard deviations below $10 \%$. The initial $\mathrm{pH}$ values were the

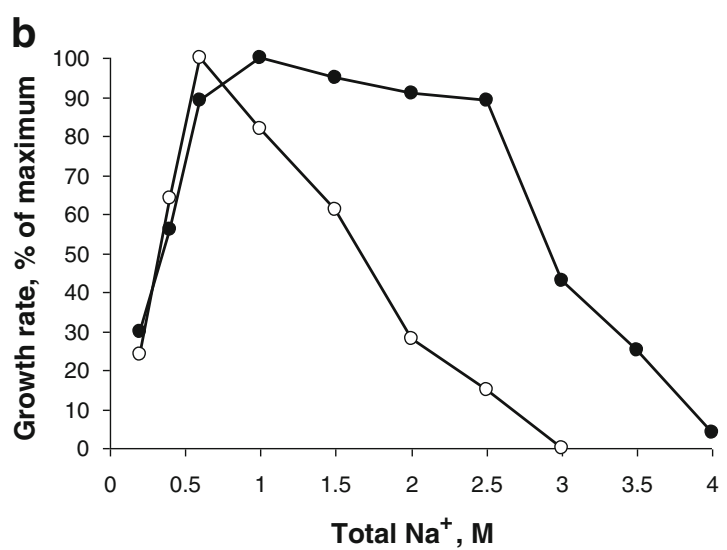

following: 8.0 (final 8.1); 8.5 (final 8.5-8.7); 9.0 (final 9.0-9.18); 9.5 (final 9.53-9.66); 9.75 (final 9.73); 10.0 (final 9.91-10.02); 10.25 (final 10.18-10.20); 10.5 (final 10.37); 10.65 (final 10.48); 10.8 (final 10.59-10.61)

Table 3 Phenotypic comparison of strains $\mathrm{AP} 3^{\mathrm{T}}$ and $\mathrm{APP} 2^{\mathrm{T}}$ with the members of the family Lachnospiraceae

\begin{tabular}{|c|c|c|c|c|}
\hline Characteristic & $\mathrm{AP} 3^{\mathrm{T}}$ & $\mathrm{APP}^{\mathrm{T}}$ & Robinsoniella peoriensis $^{\mathrm{a}}$ & $\begin{array}{l}\text { Lachnospira } \\
\text { pectinoshiza }\end{array}$ \\
\hline Cell size $(\mu \mathrm{m})$ & $0.25-0.3 \times 3-10$ & $0.25-0.4 \times 4-10$ & $0.2-0.4 \times 4.0-22.0$ & $0.3-0.5 \times 2-6$ \\
\hline Endospores &,+ terminal, round & + , terminal, round & + , subterminal & + , subterminal, round \\
\hline Motility & - & - & - & + \\
\hline Major fermentation products & Acetate, formate & Acetate, formate & $\begin{array}{l}\text { Acetate, formate, succinate, lactate, } \\
\text { ethanol }\end{array}$ & Acetate, formate \\
\hline \multicolumn{5}{|l|}{ Substrates } \\
\hline Galacturonic acid & + & + & n.d. & - \\
\hline Pectin & + & - & n.d. & + \\
\hline Polygalacturonates & + & + & n.d. & + \\
\hline Other sugars & - & $\begin{array}{l}\text { Glucuronic acid, } \\
\text { fructose }\end{array}$ & Multiple & $\begin{array}{l}\text { Fructose, lactose, } \\
\text { cellobiose }\end{array}$ \\
\hline Maximal growth temperature & 43 & 45 & n.d. & 45 \\
\hline pH range (optimum) & $8.0-10.5(9.5-9.7)$ & $8.2-10.6(10)$ & $6.9-9.3(7.8)$ & Neutrophile \\
\hline Salt range $\left(\mathrm{M} \mathrm{Na}^{+}\right)$ & $0.2-2.5$ & $0.2-3.5$ & Non-halophilic & Non-halophilic \\
\hline Polar lipids & $\begin{array}{l}\text { PG, DPG, PL, GL, } \\
\text { APL }\end{array}$ & $\begin{array}{l}\text { PG, DPG, PL, GL, } \\
\text { APL }\end{array}$ & PG, DPG, GL, APL, APGL, PE & n.d. \\
\hline $\begin{array}{l}\text { Dominant fatty acids in polar } \\
\text { lipids }\end{array}$ & $16: 0,16: 1 \omega 7 \mathrm{c}, 18: 1 \omega 7 \mathrm{c}$ & $16: 0,16: 1 \omega 7 \mathrm{c}$ & $14: 0,16: 0,16: 1 \omega 7 \mathrm{c}, 18: 1 \omega 7 \mathrm{c}$ & n.d. \\
\hline $\mathrm{G}+\mathrm{C}$ content $(\mathrm{mol} \%)$ & 30.7 & 32.0 & 48.7 & 42.0 \\
\hline Habitat & Soda soils & Soda lake sediments & Marine & Marine \\
\hline
\end{tabular}

n.d. not determined, $P G$ phosphatidylglycerol, $D P G$ diphosphatidylglycerol, $P E$ phosphatidylethanolamine, $P L$ phospolipids, $A P L$ aminophospholipids, GL glycolipids, APGL aminophosphoglycolipids

${ }^{\text {a }}$ Cornick et al. (1994)

${ }^{\mathrm{b}}$ Cotta et al. (2009)

The overall properties of the anaerobic haloalkaliphilic pectinolytic strains isolated from soda habitats of southeastern Siberian soda lakes, including large phylogenetic divergence from the closest described relatives, high salt tolerance, obligate alkaliphily and extreme metabolic specialization (summarized in comparative Table 3) suggest accommodation of the six strains into a novel genus Natranaerovirga within the order Clostridiales with uncertain 
family affiliation. Five closely related strains $\left(\mathrm{AP} 2, \mathrm{AP}^{\mathrm{T}}{ }^{\mathrm{T}}\right.$, APG1, APA1 and APG2) comprise a type species Natranaerovirga pectinivora, while a single strain $\mathrm{APP} 2^{\mathrm{T}}$ forms a second species $N$. hydrolytica.

Acknowledgments This work was supported by RFBR (10-0400152) to DS and by the Ministry of Education and Science of Russian Federation (16.552.11.7035) to AP. We are grateful to E. Detkova for the total DNA analysis and to G. Osipov for the cellular fatty acid analysis.

Open Access This article is distributed under the terms of the Creative Commons Attribution License which permits any use, distribution, and reproduction in any medium, provided the original author(s) and source are credited.

\section{Appendix 1}

Description of Natranoerovirga gen. nov.

[Natr.anaero'vir.ga; N.L. n. natron (arbitrarily derived from the Arabic n. natrun or natron) soda, sodium carbonate; N.L. pref. natrono-, pertaining to soda; Gr. pref. an, not; Gr. n. aer aeros, air; L. fem. n. virga, rod; N.L. fem. $n$. Natranaerovirga, an anaerobic rod living in soda].

Gram-positive spore-forming rods with variable length. Obligately anaerobic with fermentative metabolism. Utilize polymers of galacturonic acid as growth substrates. Obligately alkaliphilic and highly salt tolerant. Belong to the order Clostridiales. Habitats-soda lakes and soda soils. The type species is Natranaerovirga pectinivora.

\section{Appendix 2}

\section{Description of Natranaerovirga pectinivora sp. nov.}

(pec.ti.ni'vo.ra N.L. n. pectinum, pectin; L. part. adj. vora, devouring; N.L. part. adj. pectinivora, pectin-devouring).

Cells are nonmotile rods with variable length, 0.35$0.40 \times 2-20 \mu \mathrm{m}$. Gram-positive, forming ellipsoid to round terminal endospores. Strictly anaerobic fermentative saccharolytic bacteria, utilizing only galacturonic acid and its polymers, such as polygalacturonates and pectin. The final products of galacturonic acid fermentation are acetate and formate. Obligately alkaliphilic with a $\mathrm{pH}$ range for growth between 8.0 and 10.5, and an optimum at $\mathrm{pH}$ 9.7-10. High salt tolerant with a range from 0.2 to $2.5 \mathrm{M}$ $\mathrm{Na}^{+}$(optimum at 0.4-0.6 M). Mesophilic, with a maximum temperature for growth at 41-43 (type strain 43$)^{\circ} \mathrm{C}$. Catalase-negative. The polar lipids in type strain consist of phosphatidylglycerol, diphosphatidylglycerol and a range of unidentified polar, phospho-, glyco- and aminophospholipids.
The predominant fatty acids in the polar membrane lipids of the type strain include $C_{16: 0}, C_{18: 1 \omega 7 c}$ and $C_{16: 1 \omega 7 c}$. The $\mathrm{G}+\mathrm{C}$ content of the genomic DNA is 30.3-31.1 (type strain is 30.7) $\mathrm{mol} \%\left(T_{\mathrm{m}}\right)$. The type strain is AP3 ${ }^{\mathrm{T}}\left(\mathrm{DSM} 24629^{\mathrm{T}}=\mathrm{UNIQEM}\right.$ $\mathrm{U} 85^{\mathrm{T}}$ ). Isolated from soda solonchak soils in south-western Siberia. The GenBank 16S rRNA gene sequence accession number of the type strain is GQ922846.

\section{Appendix 3}

Description of Natranaerovirga hydrolytica sp. nov.

(hyd.ro'ly.ti.ca Gr. n. hydor, water; Gr. adj. lytikos, dissolving, splitting; N.L. adj. hydrolytica, polymer hydrolyzing).

Cells are nonmotile rods with variable length, $0.5-0.6 \times$ 2.5-15 $\mu \mathrm{m}$. Gram-positive, forming round terminal endospores. Strictly anaerobic fermentative saccharolytic bacterium, utilizing only galacturonic and glucuronic acids, fructose and polygalacturonates. The final products of galacturonic acid fermentation are acetate and formate. Obligately alkaliphilic with a $\mathrm{pH}$ range for growth between 8.2 and 10.6, and an optimum at $\mathrm{pH} 10$. High salt tolerant with a range from 0.2 to $3.5 \mathrm{M} \mathrm{Na}^{+}$(optimum at $1 \mathrm{M}$ ). Mesophilic, with a maximum temperature for growth at $45^{\circ}$ C. Catalase-negative. The polar lipids in type strain consist of phosphatidylglycerol, diphosphatidylglycerol and a range of unidentified polar, phospho-, glyco- and aminophospholipids. The predominant fatty acids in the polar membrane lipids of the type strain include $\mathrm{C}_{16: 0}$, and $\mathrm{C}_{16: 1 \omega 7 \mathrm{c}}$. The $\mathrm{G}+\mathrm{C}$ content of the genomic DNA is $32.0 \mathrm{~mol} \%\left(T_{\mathrm{m}}\right)$. The type strain is $\mathrm{APP}^{\mathrm{T}}\left(\mathrm{DSM} 24176^{\mathrm{T}}=\mathrm{UNIQEM} \mathrm{U806}{ }^{\mathrm{T}}\right)$. Isolated from soda lake sediments in south-western Siberia. The GenBank 16S rRNA gene sequence accession number of the type strain is GQ863487.

\section{References}

Cornick NA, Jensen NS, Stahl DA, Hartman PA, Allison MJ (1994) Lachnospira pectinoschiza sp. nov, an anaerobic pectinophile from the pig intestine. Int J Syst Bacteriol 44:87-93

Cotta MA, Whitehead TR, Falsen E, Moore E, Lawson PA (2009) Robinsoniella peoriensis gen. nov., sp. nov., isolated from a swine-manure storage pit and a human clinical source. Int J Evol Syst Microbiol 59:150-155

De Ley J, Caffon H, Reinaerts A (1970) The quantitative measurements of hybridisation DNA from renaturation rates. Eur $\mathrm{J}$ Biochem 12:133-140

Gang L, Rao L, Xuel Y, Zhou C, Zhang Y, Ma Y (2010) Cloning, expression, and characterization of a highly active alkaline pectate lyase from alkaliphilic Bacillus sp. N16-5. J Microbiol Biotechnol 20:670-677

Hoondal GS, Tiwari RP, Tewari R, Dahiya N, Beg QK (2002) Microbial alkaline pectinases and their industrial applications: a review. Appl Microbiol Biotechnol 59:409-418 
Jayani RS, Saxena S, Gupta R (2005) Microbial pectinolytic enzymes: a review. Process Biochem 40:2931-2944

Kashyap DR, Vohra PK, Chopra S, Tewari R (2001) Applications of pectinases in the commercial sector: a review. Bioresour Technol $77: 215-227$

Kates M (1972) Techniques of lipidology. American Elsevier Publishing Co., New York

Lane DJ (1991) 16S/23S rRNA sequencing. In: Stackebrandt E, Goodfellow $M$ (eds) Nucleic acid techniques in bacterial systematics. Wiley, Chichester, pp 115-177

Marmur J (1961) A procedure for isolation of DNA from microorganisms. J Mol Biol 3:208-214

Marmur J, Doty P (1962) Determination of the base composition of deoxyribonucleic acid from microorganisms. J Mol Biol 5:109-118

Miller GL (1959) Use of dinitrosalicylic acid reagent for determination of reducing sugar. Anal Chem 31:426

Omelyansky VL (1904) Histologic and chemical changes in the flux stems during pectin and cellulose fermentation. Centr Bakt XII(2)

Park HS, Kim BH, Kim HS, Kim HJ, Kim GT, Kim M, Chang IS, Park YK, Chang HI (2001) A novel electrochemically active and $\mathrm{Fe}(\mathrm{III})$-reducing bacterium phylogenetically related to Clostridium butyricum isolated from a microbial fuel cell. Anaerobe 7:297-306

Pfennig N, Lippert KD (1966) HÜber das vitamin $B_{12}$-Bedürfnis phototropher SchwefelbakterienH. Arch Mikrobiol 55:245-256
Rainey FA (2009) Order Clostridiales. In: Bergey's manual of systematic bacteriology. In: De Vos P, Garrity GM, Jones D, Krieg NR, Ludwig W, Rainey FA, Schleifer K-H, Whitman WB (eds) The Firmicutes, vol 3. Springer, Dordrecht, pp 736-1190

Sarethy IP, Saxena Y, Kapoor A, Sharma M, Sharma SK, Gupta V, Gupta S (2011) Alkaliphilic bacteria: applications in industrial biotechnology. J Ind Microbiol Biotechnol 38:769-790

Sorokin DY, Panteleeva AN, Tourova TP, Kaparullina EN, Muyzer G (2011) Natronoflexus pectinivorans gen. nov., sp. nov., an obligately anaerobic and alkaliphilic fermentative member of Bacteroidetes from soda lakes. Extremophiles 15:691-696

Sumner JB, Dounce AL (1963) Liver catalase. Methods Enzymol 2:780

van de Peer Y, de Wachter R (1994) TREECON for Windows: a software package for the construction and drawing of evolutionary trees for the Microsoft Windows environment. Comput Appl Biosci 10:569-570

Zhilina TN, Zavarzin GA, Rainey FA, Pikuta EN, Osipov GA, Kostrikina NA (1997) Desulfonatronovibrio hydrogenovorans gen. nov., sp. nov., an alkaliphilic, sulfate-reducing bacterium. Int J Syst Bacteriol 47:144-149

Zhilina TN, Appel R, Probian C, Brossa EL, Harder J, Widdel F, Zavarzin GA (2004) Alkaliflexus imshenetskii gen. nov. sp. nov., a new alkaliphilic gliding carbohydrate-fermenting bacterium with propionate formation from a soda lake. Arch Microbiol 182:244-253 